\title{
REGIONALIZACIJA LJUBLJANE Z VIDIKA HRUPNE OBREMENJENOSTI
}

Raziskava Regionalizacija Ljubljane z vidika hrupne obremenjenosti (Karta hrupa na osnovi obstoječih in nekaterih dodatnih meritev), katere naročnik je bila Mestna občina Ljubljana (Zavod za varstvo okolja), je potekala v letu 2001 in 2002. Odgovorna nosilka je bila dr. Metke Špes, pri projektu pa so sodelovali še Dejan Cigale, Barbara Lampič ter Primož Gspan in Aleš Jug s Fakultete za kemijo in kemijsko tehnologijo (Oddelek za tehniško varnost).

Kolikšen problem predstavlja hrup za Ljubljano in predvsem za njene prebivalce ter kako je prostorsko prisoten oziroma razporejen, smo ugotavljali s pomočjo meritev hrupa ter anketiranjem odzivnosti prebivalstva. Dodatno smo ugotavljali tudi stopnjo motnje hrupa nekaterih posebej občutljivih dejavnosti, za kar so bile izbrane vse osnovne in srednje šole v Ljubljani.

V okviru raziskave je bilo izvedenih preko 440 kratkotrajnih meritev na 112 različnih mestih, in sicer na območju celotnega mesta Ljubljana. Pri izboru lokacij smo dali prednost ljubljanskim stanovanjskim soseskam, saj so dosedanje meritve ob prometnicah pokazale dokaj konstantne izmerjene vrednosti.

Ugotovitve o hrupu, kakor jih omogočijo meritve ali računalniški modeli, pa ne povedo nujno, v kolikšni meri so določeni zvoki resnično moteči za okolico oziroma za ljudi, ki so tega hrupa deležni, saj je dojemanje hrupa izrazito subjektivno. Izvedba ankete med Ljubljančani (1252 veljavnih anket) je omogočila vpogled tudi v ta segment problematike in osvetlila hrup kot problem še s tega zornega kota.

- Rezultati ankete naj bi dali odgovor na vprašanje, kako ljudje doživljajo večji ali manjši hrup oziroma kolikšen problem predstavlja hrup za prebivalce Ljubljane.

Odgovori anketiranih prebivalcev Ljubljane so opozorili na številna dejstva, povezana s hrupom v mestu, med pomembnejšimi ugotovitvami pa lahko izpostavimo naslednje:

- Hrup je moteč za pomemben delež prebivalcev Ljubljane. Med anketiranci je bil največji delež tistih, ki jih hrup le malo moti (40,9\%), kar $36 \%$ anketirancev pa hrup moti močno ali zelo močno. Le slaba četrtina $v$ anketo vključenih prebivalcev $(23,1 \%)$ je izjavila, da jih hrup v stanovanju sploh ne moti.

- Hrup je moteč večji del dneva. Čeprav so anketiranci najpogosteje odgovarjali, da jih hrup moti predvsem podnevi (26,6 \% odgovorov), je bilo le malo manj (23,3\%) tistih, ki jih hrup moti predvsem ponoči. Kar petino anketirancev (20,4 \%) hrup moti ves dan.

- Kot najpomembnejši vir hrupa se je ponovno izkazal cestni promet. Tako ga je $64,1 \%$ $\mathrm{v}$ anketo vključenih prebivalcev navedlo na prvem mestu med viri motečega hrupa.

$\mathrm{Na}$ osnovi podatkov anketiranja in meritev smo določili območja z različno intenzivnim hrupom, ki smo jih tudi kartografsko prikazali.

Rezultati aplikativnega projekta so bili objavljeni v strokovni geografski in drugi literaturi pri nas in v tujini. 